\title{
Murciélagos generalistas de Costa Rica: descripción macroambiental de sitios de captura, características de hospedero y caracterización molecular de Leishmania spp. y Trypanosoma spp.
}

Randall Rubí-Chacón ${ }^{1} 凶$, Andrea Urbina-Villalobos ${ }^{1}$, Marco Herreroํㅜ, Gaby Dolz ${ }^{1}$.

1 Universidad Nacional de Costa Rica. Email: randall.rubi@gmail.com, andreaurbina3@gmail.com, herrero1958@gmail.com, gaby.dolz.wiedner@una.cr

Los murciélagos constituyen uno de los grupos de mamíferos más beneficiosos para los ecosistemas, ya que contribuyen con la dispersión de semillas, polinización de plantas y control de insectos plaga y portadores de microorganismos transmisores de enfermedades. En otros países, algunos murciélagos han sido detectados con diversos agentes infecciosos por lo que es importante conocer si alojan parásitos de Leishmania spp. y Trypanosoma cruzi, agentes endémicos en nuestro país. El objetivo de este estudio fue detectar Leishmania spp. y Trypanosoma spp., en murciélagos generalistas, al describir características del huésped, factores macroambientales de sitios de captura e identificar molecularmente los hemoparásitos para estudiar las relaciones huésped, agente, ambiente y posibles relaciones filogenéticas.

Se realizó un estudio transversal en 11 localidades de Costa Rica, donde se capturó un total de 98 murciélagos. De cada individuo se anotó el peso, sexo, grupo etario y condición reproductiva y se tomó muestras de sangre. Mediante PCR se amplificó una región del gen $18 \mathrm{~S}$ para determinar la presencia de Leishmania spp. y Trypanosoma spp. Se realizó un análisis de las características macroambientales de los sitios de captura mediante el uso de capas vectoriales del Atlas de Costa Rica, 2014 y se analizaron relaciones filogenéticas con secuencias de otros tripanosomátidos descritas anteriormente. Se determinó presencia de Leishmania spp. y Trypanosoma spp. en murciélagos Glossophaga soricina, Carollia sowelli, C. perspicillata y Artibeus jamaicensis. El peso y la precipitación se muestran como posibles variables relacionadas con la presencia de estos tripanosomátidos. Se comprueba, por primera vez en nuestro país, Leishmania spp., Trypanosoma cruzi y T. minasense sin evidencia de afectación de los murciélagos. El análisis filogenético apoya la separación de T. minasense de T. rangeli, y T. cruzi y una posible relación con tripanosomátidos suramericanos. Esta investigación contribuye al entendimiento de las relaciones filogenéticas de los hemoflagelados asociados a quirópteros del continente americano.

凶 Autor para correspondencia Randall Rubí-Chacón: randall.rubi@gmail.com 